\author{
Assistant Professor Otniel DIDRAGA, PhD \\ Email: otniel.didraga@e-uvt.ro \\ West University of Timisoara \\ Associate Professor Claudiu BRANDAS, PhD \\ Email: claudiu.brandas@e-uvt.ro \\ West University of Timisoara \\ Associate Professor Lorena BATAGAN, PhD \\ Email: lorena.batagan@ie.ase.ro \\ The Bucharest University of Economic Studies \\ Associate Professor Felician ALECU, PhD \\ Email: felician.alecu@ie.ase.ro \\ The Bucharest University of Economic Studies
}

\title{
CHARACTERISTICS OF EFFECTIVE IT PROJECT RISK MANAGEMENT IN ROMANIAN IT COMPANIES
}

\begin{abstract}
The main objective of this paper is to identify the characteristics of effective IT project risk management and to highlight their influence over the IT project performance in Romanian IT companies. We conducted a study to find out the dimensions of the risk management effectiveness and how it is applied in IT projects of Romanian IT companies. We correlated the risk management effectiveness with the performance of the IT projects (subjective and objective). All our hypotheses were confirmed. The dimensions of effective risk management are "efficiency and the effectiveness of the processes within an IT project", "influence of risks on IT projects", and "human factor involved in the IT project". Risk management effectiveness is positively correlated with the performance of these IT projects.
\end{abstract}

Key-words: Project management, Effective project risk management, Risk management characteristics, IT projects, IT project performance, Romania.

JEL Classification:C83, C87, D81, M15

\section{Introduction}

The success (or performance, by some authors) of any IT project depends not only on the triple classical constraints: budget, time, quality/scope, but also on risks, resources, different perception of the stakeholders, project value, process quality, communication and interaction between the parties involved. Managing the risks is mainly about prevention rather than dealing with the results of the happening of any unwanted or unexpected event (PMI, 2017, Agarwal and Rathod, 
Otniel Didraga, Claudiu Brandas, Lorena Batagan, Felician Alecu

2006). An essential activity of any project manager is related to plan the proper actions for the identified project risks, so if such an event is happening, the project team should be able to quickly react according to the plan by taking the most appropriate actions to resolve the situation.

The paper is structured as follows.

The first part presents the literature review of risk management and IT project concepts, establishing the correlations between them. Researchers worldwide are interested in risk management by implementing the latest innovations in this field. Risk management is an essential element for a successful IT project. Project managers can minimize the risk. The researchers (Spacey, 2016; Zwikael and Ahn, 2011) defined Risk Management Effectiveness as"the percentage of loss events that were managed as risks before they occurred". On the other hand, the literature review (Górecki, 2018; Scheepers and Whelpton, 2018;Javani and Rwelamila, 2016; Rekha, 2015; Rabechini Junior and Carvalho, 2013) highlights that risk management effectiveness can be correlated with the performance of IT projects and can help to control and minimize the impact of unfortunate situations or events. In this case, it is very important to identify the characteristics of effective IT Projects risk management in Romanian IT companies.

The second part presents the research methodology consisting of presenting a research model validated through an online questionnaire applied to a 361-company database between 2012 and 2018.

The third part of the paper presents the results of our study about the dimensions of risk management effectiveness and how they apply in IT projects in Romanian IT companies.

The fourth part emphasizes conclusions and future objectives regarding risk management.

\section{Risk Management in IT Project Management}

The major benefits of risk management can always be counted in terms of saved time and money. Thus, the management of risks is one of the most important aspects of the project management practice and discipline because it helps to prevent many problems and makes other situations to become less likely to appear, so risk management is critical for the success of any project.

Usually, when risks occur, they need to be identified, assessed, and mitigated to cover their effects on the project. The paper aims to identify the characteristics of effective IT project risk management and their influence on the performance of IT projects in IT companies in Romania.

Regularly, the risk management details are properly defined during the project planning phase, and the project execution involves risk responses while the controlling phase also includes the monitor risks activities(Chapman, 2017). Despite these, risks can be identified at any time, so the project risks are continuously reassessed and updated during the entire project lifecycle. 
Typically, the risks can be categorized into four main areas(PMI, 2017):

- Internal - related to people, time, money, project scope, etc.;

- External - regarding legislation, regulations, government, environment, etc.;

- Technical - challenges of technological change;

- Unanticipated - for example, a meteorite striking the data center facility (Shi, 2018).

The usual techniques used to identify the risks related to a project are (Didraga, 2013):

- Checklists - usually generated on the lessons learned of other projects and updated based on the current project particularities;

- Risk Breakdown Structure - the risks are represented hierarchically;

- Brainstorming - any idea might generate a new one.

All the identified risks are recorded in a project risk register together with all the possible responses. Next, all the identified risks should be analyzed from a qualitative and quantitative point of view.

The qualitative risk analysis is done by creating a probability and impact matrix that represents a subjective evaluation (on a predefined scale, like 1-10 or low/medium/high) of probability to occur of any risk together with the associated impact if it is really happening, so the risks can be prioritized by their rating in terms of probability and impact.

Most of the time, companies are using a standard risk rating system promoting a common understanding regarding the significance of each identified risk, no matter who does the risk assessment. An example of such a standard probability and impact matrix is presented in Table 1.

Table 1. Example of standardized probability and impact matrix within a company/department/project

\begin{tabular}{|c|c|c|c|c|c|c|}
\cline { 3 - 7 } \multicolumn{2}{c|}{} & \multicolumn{6}{c|}{ Impact } \\
\cline { 2 - 7 } \multicolumn{1}{c|}{} & $\begin{array}{c}\text { Trivial } \\
<0.1\end{array}$ & $\begin{array}{c}\text { Minor } \\
{[0.1,0.3)}\end{array}$ & $\begin{array}{c}\text { Moderate } \\
{[0.3,0.7]}\end{array}$ & $\begin{array}{c}\text { Major } \\
(0.7,0.9]\end{array}$ & $\begin{array}{c}\text { Extreme } \\
>0.9\end{array}$ \\
\hline \multirow{4}{*}{ Probability } & $\begin{array}{c}\text { Almost impossible } \\
<0.1\end{array}$ & Low & Low & Low & Moderate & Moderate \\
\cline { 2 - 7 } & $\begin{array}{c}\text { Unlikely } \\
{[0.1,0.25)}\end{array}$ & Low & Low & Moderate & Moderate & Moderate \\
\cline { 2 - 7 } & $\begin{array}{c}\text { Moderate } \\
{[0.25,0.75]}\end{array}$ & Low & Moderate & Moderate & Moderate & High \\
\cline { 2 - 7 } & $\begin{array}{c}\text { Likely } \\
(0.75,0.9]\end{array}$ & Moderate & Moderate & Moderate & High & High \\
\cline { 2 - 7 } & $\begin{array}{c}\text { Almost certain } \\
>0.9\end{array}$ & Moderate & Moderate & High & High & High \\
\hline
\end{tabular}

The quantitative part involves a numerical analysis of the probability and impact, so it is about a more objective perspective than the qualitative one by using several techniques like decision trees or simulations. Such quantitative analysis of risks is usually generating a better-prioritized list of counted risks. 
When quantifying a risk, we can consider the probability or the impact, but analyzing both can generate a better overall ranking of the project risks. The EMV (Expected Monetary Value) can be successfully used in risk ranking. It is a very useful indicator, and it can be easily computed, as presented below.

$$
E M V_{R}=P_{R} * I_{R}
$$

where $P_{R}$ is the probabilily of risk $R$, and $I_{R}$ is its impact

We can also compute EMV at the project level by summarizing the individual EMVs computed for each project risk, as in formula no.2.

$$
E M V=\sum_{R=1}^{N} E M V_{R}=\sum_{R=1}^{N}\left(P_{R} * I_{R}\right)
$$

where $N$ represents the number of risks identified within the project

In various proportions depending on the probability, impact, and expected monetary value, all the identified risks are contributing to the project reserves.

Contingency reserves are covering the project residual risks (already identified risks that remain after completing the risk management process). For example, having a $10 \%$ probability of receiving the main servers late from the manufacturer in China, with a project cost of $2000 €$, were the project manager has to setup a reserve of $200 €$. These reserves are contributing to the overall project cost baseline because some risks will remain active in the project, so they need their separate budget.

Project Cost Baseline $=\sum$ (Activity Estimates $)+\sum($ Contingency Reserves $)$

Management reserves are for risks that were not identified during the risk management process. These risks, being unknown, cannot be expressed in terms of expected monetary value simply because the project manager does not know anything about them in advance in terms of probability of occurrence, or impact. This reason is why the management reserves are estimated as a percent of the project cost; usually, the value is between $3 \%$ and $10 \%$,but it depends on the project complexity, contributing to the overall project budget.

$$
\text { Project Budget } \left.=\sum \text { (Activity Estimates }\right)+\sum(\text { Contingency Reserves })+(\text { Management Reserves })
$$

Considering possible risk responses, the most common strategies are (Didraga, 2013):the avoidance (eliminating the factors that can generate the risk), the mitigation (reduce the probability and/or the impact of the risk occurrence), or 
transfer (making another entity responsible, like making an insurance, but it will still be some impact over the project for the situation when the risk really occurs).

Recent studies have shown the link between risk management and IT project success (Scheepers and Whelpton, 2018; Javani and Rwelamila, 2016; Didraga, 2013; de Bakker, 2010, 2011; Pimchangthong and Boonjing, 2017).

Risk management (Górecki, 2018; Rekha, 2015; Rabechini Junior and Carvalho 2013) represents the identification, evaluation, analyzing and prioritization of risks to identify, monitor, control and minimize the impact of unfortunate events. Risk management helps us to manage the risk and plays a key role in project management methodology (Górecki, 2018; Rekha, 2015). In our modern society, it is essential to intensively use risk management since it represents an effective solution to manage the risk by identifying, monitoring, and controlling it during the process. In IT projects, it is essential to identify the risk in real time and to monitor and control the risk (Rekha, 2015). The risk can appear in any phase of an IT project, and thus it can be identified during the requirements gathering, data analysis, planning, design of the software, management of human resources, implementation and integration of modules, etc. For each IT project, it is essential to measure the risk of each phase.

In the existing literature (Górecki, 2018; Rekha, 2015; Rabechini Junior and Carvalho 2013), different types of risks are defined for IT projects:

- Analysis Risk -problems related to the proper understanding of requirements;

- Operational Risk - issues associated with resource management or task planning;

- Technical Risk -subjects related to software or hardware problems;

- Financial Risk - project budget management issues.

The risk management of any IT project is essential for project success and represents real support in reducing the dimensions of the risks involved. In this case, we need to correlate the efficiency of a project with the risk management processes.

Risk management is an integral part of the project strategy, and it is based on initial planning. It is an essential part of making decisions. Risk management helps achieve overall project success, helps increase the efficiency and the effectiveness of the processes within the project, helps clarify the processes within the project, helps continuously identify risks, helps classify and assess the risks correctly, helps increase the information security within the project, helps predict risks in future similar projects and helps to obtain deliverables.

Risk management reduces the level of risks and reduces the possible negative impact. Project managers can minimize the risks by using different types of methods like analyses, communication, authoritative decision, or delegation. The main objective of risk management is to identify the risks and to ensure they are eliminated, diminished, or mitigated. Risk management effectiveness is defined in the existing literature (Spacey, 2016; Zwikael and Ahn,2011) as the percentage 
Otniel Didraga, Claudiu Brandas, Lorena Batagan, Felician Alecu

of eliminated events that were managed as risks before they occurred. In any project, the risk management effectiveness has a positive influence on managers' decisions, system quality, and client satisfaction.

\section{Research methodology}

\subsection{Research design and tools}

We applied an online questionnaire to a 361-company database between 2012 and 2018. The target population consisted of project managers, IT managers, and IT analysts. We used convenience sampling and snowball sampling techniques. The questions referred to the most recent completed IT project the respondents took part in. The data were processed in spreadsheet software and imported in IBM@ SPSS. The statistical analysis consisted of five stages:

1. the univariate descriptive analysis,

2. checking the reliability of the used scales,

3. the factor analysis,

4. the construct validity analysis and

5. the hypothesis testing.

In our research, we developed the hypothesis H1: Risk management effectiveness is positively correlatedwith the performance of the IT project.

Based on the identified components of our analysis, we further developed the following hypotheses:

- H1a-Risk management effectiveness is positively correlated with the subjective performance of the IT project

- $\boldsymbol{H} \mathbf{1 b}$ - Risk management effectiveness is positively correlated with the objective performance of the IT project

- H1b1-Risk management effectiveness is negatively correlated with project cost overrun

- H1b2 - Risk management effectiveness is negatively correlated with project schedule overrun

- H1b3 - Risk management effectiveness is negatively correlated with project effort overrun

For the hypothesis testing phase, we used the univariate descriptive analysis, the t-Student comparison test, the ANOVA test, the r-Pearson correlation test, and the linear regression in SPSS.

3.2 The performance of IT Projects

Although many reasons can lead to project failure, "inappropriate risk management and control is undoubtedly one of the main factors" (Na et al., 2007).

Many frameworks are trying to explain "different types of software project risks, risk management strategies, and project success measurements" (Fairley, 1994; Nidumolu, 1996b; Wallace et al., 2004; Agarwal and Rathod, 2006). Most of these studies relate to "software risk control in developed countries with sophisticated software development infrastructures"."Software development 
performance" can be grouped into two main categories (Na et al., 2007; Jun et al., 2011):subjective performance and objective performance.

\subsubsection{The subjective performance of an IT project}

Subjective performance can be assessed by the opinion of those involved in the project (Wohlin et al., 2000). While this technique has the benefit of ease of data collection, it becomes difficult when generalizing data because project evaluation depends on the manager's specific judgment (Gray et al., 1999). Two commonly used constructs are "process performance" and "product performance". These two subjective performance measures have been extensively debated in the software development literature (Nidumolu, 1996b; Wallace et al., 2004; Na et al., 2007; Jun et al. 2011).

Process performance is "a performance metric of software development processes" (Nidumolu, 1996b; Na et al., 2007). Product performance is "a performance metric that represents the performance of the final product" (Nidumolu, 1996b; Na et al., 2007). We used a 5 step Likert scale ("Strongly disagree" - "Strongly agree") with eight items. Table 2 contains the variables of the construct "Subjective Performance".

Table 2. Operationalization of the "Subjective Performance of an IT Project"

\begin{tabular}{|c|c|c|c|}
\hline Construct & $\begin{array}{r}\text { Construct } \\
\text { dimensions }\end{array}$ & Construct operationalization (variables) & $\begin{array}{l}\text { Variable } \\
\text { code }\end{array}$ \\
\hline \multirow{8}{*}{$\begin{array}{l}\text { Subjective } \\
\text { performance } \\
\text { of an IT } \\
\text { project }\end{array}$} & \multirow{6}{*}{$\begin{array}{l}\text { A. IT product } \\
\text { performance }\end{array}$} & The final software/system is reliable & 1.A.1 \\
\hline & & The final software/system is easy to use & 1.A.2 \\
\hline & & The final software/system is flexible & $1 . \mathrm{A} .3$ \\
\hline & & $\begin{array}{l}\text { The final software/system meets the functional } \\
\text { requirements of the users }\end{array}$ & 1.A.4 \\
\hline & & The users are happy with the delivered software/system & $1 . \mathrm{A} .5$ \\
\hline & & General quality of the software/system is very good & 1.A.6 \\
\hline & \multirow{2}{*}{$\begin{array}{l}\text { B. Process } \\
\text { performance }\end{array}$} & The project was completed within budget & 1.B.1 \\
\hline & & The project was completed within schedule & $1 . \mathrm{B} .2$ \\
\hline
\end{tabular}

\subsubsection{The objective performance of an IT project}

The "objective performance" includes "quantifiable measures, such as cost, effort, and schedule" (Gray et al., 1999). Since software performance measures have "different implications for different organizations", existing literature often recommends the use of both types of performance, subjective and objective measures (Didraga, 2013; Gray et al., 1999). For example, for software developers, their customers are more interested in measurable performance targets. Most existing research on the performance of software development projects focuses on developers rather than organizations that order (or acquire) software. This scale was used by Nidumolu (1996b), Na et al. (2007), Jun et al. (2011). Table 3 contains the variables of the construct "Objective Performance". 
Otniel Didraga, Claudiu Brandas, Lorena Batagan, Felician Alecu

Table 3. Operationalization of the "Objective Performance of an IT Project"

\begin{tabular}{|l|l|c|}
\hline \multicolumn{1}{|c|}{ Construct } & Construct operationalization (variables) & Variable code \\
\hline \multirow{2}{*}{$\begin{array}{l}\text { Objective performance of an } \\
\text { IT project }\end{array}$} & Cost overrun & 2 \\
\cline { 2 - 3 } & Schedule overrun & 3 \\
\cline { 2 - 3 } & Effort overrun & 4 \\
\hline
\end{tabular}

3.3 Risk management effectiveness

By transposing the principles set in ISO 31000 (ISO, 2018), the features of Teymouri and Ashoori (2011), Galorath and Evans (2006), and de Bakker (2010, 2011), we proposed a characterization of effective risk management in IT projects. We used a 5 step Likert scale ("Strongly disagree" - "Strongly agree") with 23 items.

Table 4 contains the 23 variables proposed for the construct "Risk management effectiveness".

Table 4. Operationalization of the "Risk management effectiveness"

\begin{tabular}{|c|c|c|}
\hline Construct & Construct operationalization (variables) & Variable code \\
\hline \multirow{23}{*}{$\begin{array}{l}\text { Risk } \\
\text { management } \\
\text { effectiveness }\end{array}$} & Was an integral part of the project strategy & 5.1 \\
\hline & Was based on the commitment of the team leaders; & 5.2 \\
\hline & Was based on initial planning; & 5.3 \\
\hline & Was considered in making decisions; & 5.4 \\
\hline & Was transparent and dynamic; & 5.5 \\
\hline & $\begin{array}{l}\text { Was conducted systematically, structured and on time (proactive } \\
\text { and continuously); }\end{array}$ & 5.6 \\
\hline & Positively influenced managers' decisions; & 5.7 \\
\hline & Explicitly referred to uncertainties and risks in the current project; & 5.8 \\
\hline & Helped identify risks continuously; & 5.9 \\
\hline & Helped classify and assess the risks correctly; & 5.10 \\
\hline & Reduced the probability of risks; & 5.11 \\
\hline & Reduced the possible negative impact of risks; & 5.12 \\
\hline & Reduced the overall exposure to risks (probability $\mathrm{x}$ impact); & 5.13 \\
\hline & Was tailored and based on the best information available; & 5.14 \\
\hline & Considered the human factor (stakeholders); & 5.15 \\
\hline & $\begin{array}{l}\text { Helped increase the efficiency and the effectiveness of processes } \\
\text { within the project; }\end{array}$ & 5.16 \\
\hline & Helped clarify the processes within the project; & 5.17 \\
\hline & Helped increase the information security within the project; & 5.18 \\
\hline & Helped to obtain deliverables; & 5.19 \\
\hline & Positively influenced system quality; & 5.20 \\
\hline & Positively influenced client satisfaction; & 5.21 \\
\hline & Helped achieve overall project success; & 5.22 \\
\hline & Will help predict risks in future similar projects & 5.23 \\
\hline
\end{tabular}

\section{Results}

4.1. Descriptive analysis

We received a total number of 210 answers, out of which we validated 208 questionnaires from 85 companies $(23.54 \%)$. We received more than one answer from some companies where there were several IT project managers. 
Most companies in the sample of 85 were small companies (under ten employees), 83\% were SMEs (under 250 employees), and large companies (over 250 employees), $17 \%$.

Most of the respondents (57\%) were project managers, $29 \%$ were in a managerial position, and the rest of $14 \%$ were analysts of IT consultants.

Most of the respondents were involved in a few projects (1-3 projects) $27 \%$ and $18 \%$ of them were involved in over 20 projects.

\subsection{Scale reliability}

The 8-item scale used to measure the "subjective performance of the IT projects" has a level of 0.853 , indicating a reliable scale. After analyzing Table 5, we can say that eliminating any variable would lead to a decrease in the value of Cronbach's Alpha coefficient (Table 5).

The value of the KMO test is 0.823 (>0.7), and the Bartlett test value is 740.23 (significance level $\mathrm{p}<0.01$ ). Thus, among the eightvariables, there are significant correlations, which can be studiedthrough factor analysis. The Extraction Method used was the Principal Component Analysis.

Table 5.Reliability of the scale for "Subjective Performance of an IT Project"

\begin{tabular}{|c|c|c|c|c|}
\hline Variable & $\begin{array}{l}\text { Cronbach's } \\
\text { Alpha if } \\
\text { Item } \\
\text { Deleted }\end{array}$ & $\begin{array}{c}\text { Component } \\
\text { Matrix - } \\
\text { factor } \\
\text { loadings }\end{array}$ & $\begin{array}{c}\text { Final } \\
\text { Cronbach's } \\
\text { Alpha }\end{array}$ & $\begin{array}{c}\text { Final } \\
\text { Component } \\
\text { Matrix - } \\
\text { factor } \\
\text { loadings } \\
\end{array}$ \\
\hline 1.A.1. The final software/system is reliable & .830 & .656 & \multirow{8}{*}{\multicolumn{2}{|c|}{ No variable was deleted }} \\
\hline $\begin{array}{l}\text { 1.A.2. The final software/system is easy to } \\
\text { use }\end{array}$ & .832 & .555 & & \\
\hline 1.A.3. The final software/system is flexible & .835 & .689 & & \\
\hline $\begin{array}{l}\text { 1.A.4. The final software/system meets the } \\
\text { functional requirements of the users }\end{array}$ & .832 & .682 & & \\
\hline $\begin{array}{l}\text { 1.A.5. The users are happy with the } \\
\text { delivered software/system }\end{array}$ & .836 & .928 & & \\
\hline $\begin{array}{l}\text { 1.A.6. General quality of the } \\
\text { software/system is very good }\end{array}$ & .829 & .887 & & \\
\hline $\begin{array}{l}\text { 1.B.1. The project was completed within } \\
\text { budget }\end{array}$ & .835 & .753 & & \\
\hline $\begin{array}{l}\text { 1.B.2. The project was completed within } \\
\text { schedule }\end{array}$ & .850 & .779 & & \\
\hline
\end{tabular}

Using the Keiser criterion to limit the number of extracted factors (Eigenvalue $=1$ ), we selected two factors explaining $65.31 \%$ of the total variance of the eight variables. Factor loadings were high enough (minimum: 0.555, Table 5 ), so we did not remove any variables. Under these circumstances, factor scores were calculated, considering all eight variables.

All eight variables of the construct are significantly correlated two by two, at a significance level of 0.01 . In these circumstances, we consider that the construct "Subjective Performance of an IT Project" shows convergent validity. 
Otniel Didraga, Claudiu Brandas, Lorena Batagan, Felician Alecu

The 23-item scale used to measure "risk management effectiveness" is a proprietary scale based on literature in the field (ISO, 2018; Teymouri and Ashoori, 2005). For this reason, the approach was an exploratory one from general to particular.

Cronbach's Alpha for the scale is 0.928 , indicating a very reliable scale. Analyzing table6, we can see that eliminating variables 5.1, 5.2, and 5.23 would lead to an increased value of the Cronbach's Alpha coefficient. After eliminating the three variables, Cronbach's Alpha for the scale increased to 0.937 .

Table 6. Scale reliability for "risk management effectiveness"

\begin{tabular}{|c|c|c|}
\hline Variable & $\begin{array}{c}\text { Cronbach's } \\
\text { Alpha if Item } \\
\text { Deleted } \\
\text { (stage 1) } \\
\end{array}$ & $\begin{array}{c}\text { Cronbach's } \\
\text { Alpha if Item } \\
\text { Deleted } \\
\text { (stage 2) } \\
\end{array}$ \\
\hline 5.1. Was an integral part of the project strategy & .929 & - \\
\hline 5.2. Was based on the commitment of the team leaders; & .931 & - \\
\hline 5.3. Was based on initial planning; & .927 & .936 \\
\hline 5.4. Was considered in making decisions; & .926 & .936 \\
\hline 5.5. Was transparent and dynamic; & .926 & .936 \\
\hline $\begin{array}{l}\text { 5.6. Was conducted systematically, structured and on time (proactive and } \\
\text { continuously); }\end{array}$ & .925 & .934 \\
\hline 5.7. Positively influenced managers' decisions; & .924 & .933 \\
\hline 5.8. Explicitly referred to uncertainties and risks in the current project; & .926 & .936 \\
\hline 5.9. Helped identify risks continuously; & .924 & .933 \\
\hline 5.10. Helped classify and assess the risks correctly; & .923 & .932 \\
\hline 5.11. Reduced the probability of risks; & .924 & .933 \\
\hline 5.12. Reduced the possible negative impact of risks; & .923 & .932 \\
\hline 5.13. Reduced the overall exposure to risks (probability x impact); & .925 & .934 \\
\hline 5.14. Was tailored and based on the best information available; & .924 & .934 \\
\hline 5.15. Considered the human factor (stakeholders); & .925 & .935 \\
\hline $\begin{array}{l}\text { 5.16. Helped increase the efficiency and the effectiveness of processes } \\
\text { within the project; }\end{array}$ & .923 & .932 \\
\hline 5.17. Helped clarify the processes within the project; & .924 & .934 \\
\hline 5.18. Helped increase the information security within the project; & .925 & .935 \\
\hline 5.19. Helped to obtain deliverables; & .924 & .933 \\
\hline 5.20. Positively influenced system quality; & .922 & .931 \\
\hline 5.21. Positively influenced client satisfaction; & .924 & .933 \\
\hline 5.22. Helped achieve overall project success; & .922 & .931 \\
\hline 5.23. Will help predict risks in future similar projects & .930 & - \\
\hline
\end{tabular}

The value of the KMO test is 0.873 (> 0.7), and the Bartlett spherical test value is 2876.93 (significance level $\mathrm{p}<0.01$ ). Thus, the significant intercorrelations among the remaining 20 variables can be further studied using factor analysis.

\subsection{Factor analysis}

The method of extracting factors in the applied exploratory factor analysis was Principal Component Analysis, and the rotation method used was Varimax, to facilitate the interpretation of the extractedfactors.

Using the Kaiser criterion to limit the number of extracted factors (Eigenvalue $>1$ ), we extractedthreefactors, which cumulatively explain $62.44 \%$ of the total variance of the 20 variables. 
Table 7- step 1 contains the factor loadings for the 20 variables. We can see that two of these variables have a maximum factor loading of less than 0.5 , which means that they are not strongly correlated with any of the three components. These variables (5.8 and 5.14) were removed from the subsequent statistical analyses.

Next, we resumed the exploratory factor analysis procedure for the remaining 18 variables, also with the Varimax rotation method. Using the Kaiser criterion to limit the number of extracted factors (Eigenvalue>1), we extractedthree factors that cumulatively explain $65.44 \%$ of the total variance of the remaining 18 variables.

Table7.Factor loadings matrix for "Risk management effectiveness" (step 1 - 20 variables, step 2 - 18 variables)

\begin{tabular}{|c|c|c|c|}
\hline Variable & $\mathbf{1}$ & $\mathbf{2}$ & $\mathbf{3}$ \\
\hline 5.3 & .440 & -.046 & .571 \\
5.4 & .039 & .282 & .711 \\
5.5 & .275 & .050 & .738 \\
5.6 & .617 & .092 & .452 \\
5.7 & .742 & .268 & .167 \\
$\mathbf{5 . 8}$ & $\mathbf{. 4 3 8}$ & $\mathbf{. 6 4}$ & $\mathbf{. 2 7 3}$ \\
5.9 & .713 & .115 & .376 \\
5.10 & .734 & .310 & .252 \\
5.11 & .735 & .437 & -.035 \\
5.12 & .762 & .404 & .050 \\
5.13 & .543 & .447 & .023 \\
$\mathbf{5 . 1 4}$ & $\mathbf{. 4 2 9}$ & $\mathbf{. 3 2 9}$ & $\mathbf{. 3 6 8}$ \\
5.15 & .013 & .419 & .709 \\
5.16 & .286 & .732 & .352 \\
5.17 & .225 & .692 & .233 \\
5.18 & .188 & .863 & -.003 \\
5.19 & .330 & .638 & .193 \\
5.20 & .359 & .736 & .303 \\
5.21 & .248 & .490 & .544 \\
5.22 & .483 & .612 & .327 \\
\hline
\end{tabular}

\begin{tabular}{|c|c|c|c|}
\hline Variable & $\mathbf{1}$ & $\mathbf{2}$ & $\mathbf{3}$ \\
\hline 5.3 & -.046 & .446 & $\mathbf{. 5 8 7}$ \\
5.4 & .290 & .030 & $\mathbf{. 7 0 8}$ \\
5.5 & .059 & .265 & $\mathbf{. 7 4 6}$ \\
5.6 & .102 & $\mathbf{. 6 0 9}$ & .462 \\
5.7 & .277 & $\mathbf{. 7 2 9}$ & .170 \\
5.9 & .126 & $\mathbf{. 6 9 3}$ & .374 \\
5.10 & .311 & $\mathbf{. 7 4 2}$ & .270 \\
5.11 & .430 & $\mathbf{. 7 5 2}$ & -.017 \\
5.12 & .401 & $\mathbf{. 7 7 0}$ & .065 \\
5.13 & .453 & $\mathbf{. 5 3 0}$ & .016 \\
5.15 & .426 & .003 & $\mathbf{. 7 0 6}$ \\
5.16 & $\mathbf{. 7 3 9}$ & .281 & .350 \\
5.17 & $\mathbf{. 7 0 3}$ & .205 & .215 \\
5.18 & $\mathbf{. 8 6 2}$ & .187 & -.011 \\
5.19 & $\mathbf{. 6 3 4}$ & .342 & .201 \\
5.20 & $\mathbf{. 7 3 8}$ & .356 & .303 \\
5.21 & .499 & .241 & $\mathbf{. 5 4 5}$ \\
5.22 & $\mathbf{. 6 1 6}$ & .481 & .331 \\
\hline
\end{tabular}

Table 7 - step 2 contains the resulting factor loadings. We can see that all variables have a factor loading higher than 0.5 , so we do not have to remove any more variables.

We can explain the extracted components, and we can link them at a theoretical level with the construct "Risk Management Effectiveness": component (1) refers to the efficiency and effectiveness of project processes; component (2) refers to the influence of risk management processes on the risks of computer projects; component (3) refers to the human factor involved in the IT project. The three dimensions identified were coded as distinct variables, with the following codes:

- PMR_Efic_proces (Efficiency and effectiveness of project processes);

- PMR_Infl_risc (Influence of Risk Management on Risks); 
Otniel Didraga, Claudiu Brandas, Lorena Batagan, Felician Alecu

- PMR_Fct_uman (Human factor involved in the project).

Starting from these dimensions, we performed the $2^{\text {nd }}$ order factor analysis to calculate the factorial scores for the construct "Risk Management Effectiveness".

The Cronbach's Alpha coefficient of the studied construct scale is 0.842 , indicating the reliability of the measuring instrument. In Table 8 , we can see that no identified variable has a negative impact on the reliability of the scale.

Considering the three variables, we calculated the factorial scores for the construct "Risk Management Effectiveness". Using the Kaiser extraction criterion (Eigenvalue $>1$ ), we extracted one factor that explains $76.04 \%$ of the total variance of its three dimensions. Factor loadings are presented in Table 8.

Table8. Scale reliability and factor loadings for "Risk management effectiveness" -3 dimensions

\begin{tabular}{|l|c|c|}
\hline \multicolumn{1}{|c|}{ Variable } & Cronbach's Alpha if Item Deleted & Factor loadings \\
\hline PMR_Efic_proces & .841 & .831 \\
PMR_Infl_risc & .771 & .879 \\
PMR_Fct_uman & .723 & .904 \\
\hline
\end{tabular}

\subsection{Construct validity analysis}

Bivariate correlations between the final 18 variables are significant for significance levels of 0.01 and 0.05 except for the next pair of variables: 5.3 - 5.18. The significance of this correlation is 0.212 . We believe that,although the size of the sample is small, we must remove variable 5.18 to result in the construct "Risk Management Effectiveness" having a convergent validity. Thus, we removed variable 5.18 from further statistical analyses.

We computed new variables for the construct "Risk Management Effectiveness" and "Subjective Performance of the IT Project", and we tested the constructs for discriminant validity. We proved that both constructs have convergent and discriminant validity.

\subsection{Hypothesis testing}

Finally, we performed a regression analysis to test the correlations between the constructs. For the simple linear regression, we used the following formula:

$$
Y=\alpha+\beta * X
$$

where:

$\mathrm{Y}=$ the dependent variable (for $\mathrm{H} 1 \mathrm{a}$ - subjective performance of the IT project; for $\mathrm{H} 1 \mathrm{~b} 1$ - cost overrun; for $\mathrm{H} 1 \mathrm{~b} 2$ - schedule overrun; for $\mathrm{H} 1 \mathrm{~b} 3$ - effort overrun);

$\alpha, \beta=$ the parameters of the regression model;

$\mathrm{X}=$ the independent variable (risk management effectiveness).

Hypothesis H1-Risk management effectiveness is positively correlatedwith the performance of the IT project

HIa - Risk management effectiveness is positively correlated with the subjective performance of the IT project 
The H1a hypothesis is accepted; the significance level is 0.000 (Table 9). The value of the unstandardized coefficient of the regression function is 0.336 ,and the value of the t-statistic is 4.904 . The value of the $\mathrm{R}$ correlation coefficient is 0.323 , which indicates the existence of a low to a medium intensity relationship between the risk management effectiveness and the subjective performance of the IT project. The $\mathrm{R}$ Square determination coefficient points out that "risk management effectiveness" explains $10.5 \%$ of the variation of "the subjective performance of the IT project" construct.

$\boldsymbol{H} \mathbf{1 b}$ - Risk management effectiveness is positively correlated with the objective performance of the IT project

Hlb1 - Risk management effectiveness is negatively correlated with project cost overrun

The H1b1 hypothesis is accepted; the significance level is 0.000 (Table 9). The value of the unstandardized coefficient of the regression function is -11.339 , and the value of the $t$-statistic is -5.463 . The value of the $\mathrm{R}$ correlation coefficient is 0.356 , which indicates the existence of a low to medium intensity relationship between the risk management effectiveness and the cost overrun of the IT project. The $\mathrm{R}$ Square determination coefficient points out that "risk management effectiveness" explains $12.7 \%$ of the variation of "cost overrun of the IT project".

H1b2 - Risk management effectiveness is negatively correlated with project schedule overrun

The H1b2 hypothesis is accepted; the significance level is 0.000 (Table 9). The value of the unstandardized coefficient of the regression function is -12.957 , and the value of the t-statistic is -5.799 . The value of the $\mathrm{R}$ correlation coefficient is 0.375 , which indicates the existence of a low to medium intensity relationship between the risk management effectiveness and the schedule overrun of the IT project. The R Square determination coefficient points out that "risk management effectiveness" explains $14.0 \%$ of the variation of "schedule overrun of the IT project".

Hlb3 - Risk management effectiveness is negatively correlated with project effort overrun

The H1b3 hypothesis is accepted; the significance level is 0.000 (Table 9). The value of the unstandardized coefficient of the regression function is -9.256 , and the value of the $\mathrm{t}$-statistic is -4.192 . The value of the $\mathrm{R}$ correlation coefficient is 0.280 , which indicates the existence of a low-intensity relationship between the risk management effectiveness and the effort overrun of the IT project. The $\mathrm{R}$ Square determination coefficient points out that "risk management effectiveness" explains $7.9 \%$ of the variation of "effort overrun of the IT project".

A summary of the research results is presented in figure 1 and Table 9. 
Otniel Didraga, Claudiu Brandas, Lorena Batagan, Felician Alecu

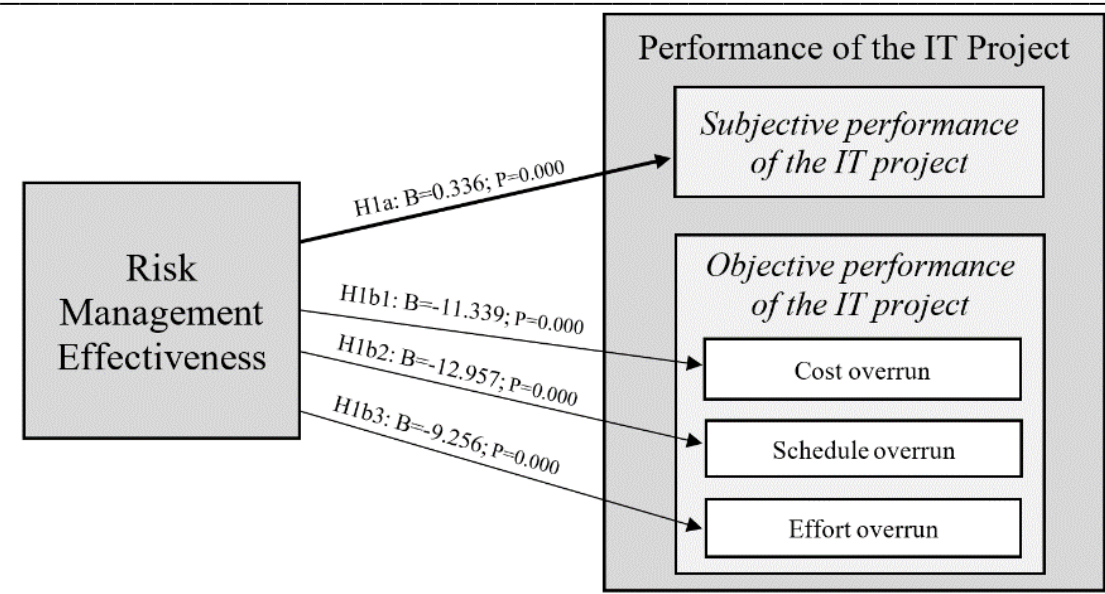

Figure 1. Research results and final model

Table 9. Hypothesis test results

\begin{tabular}{|c|c|c|c|c|c|c|c|}
\hline Hypothesis & $\mathbf{R}$ & $\begin{array}{c}\mathbf{R} \\
\text { Square }\end{array}$ & Constant $(\boldsymbol{\alpha})$ & $\begin{array}{c}\text { Unstandardized } \\
\text { Coefficient B( }(\boldsymbol{\beta})\end{array}$ & $\begin{array}{c}\mathbf{t}- \\
\text { Statistic }\end{array}$ & $\begin{array}{c}\text { Significance } \\
\text { level }\end{array}$ & Result \\
\hline H1a & 0.323 & 0.105 & 2.738 & 0.336 & 4.904 & 0.000 & Accepted \\
\hline H1b1 & 0.356 & 0.127 & 50.433 & -11.339 & -5.463 & 0.000 & Accepted \\
\hline H1b2 & 0.375 & 0.140 & 57.589 & -12.957 & -5.799 & 0.000 & Accepted \\
\hline H1b3 & 0.280 & 0.079 & 42.716 & -9.256 & -4.192 & 0.000 & Accepted \\
\hline
\end{tabular}

The IT project managers' perception of the performance of risk management is positively correlatedwith the perception of the subjective performance (IT product and project processes) of the IT project. A proper identification, assessment, treatment, monitoring, and control of the IT project determines the performance of the IT project regarding costs compliance, time, and system quality criteria.

\section{Conclusions and future work}

A theoretical implication of this research is the definition of the concept of "effective risk management"; it is associated with project risk management effectiveness. We consider that risk management must be more than effective in the context of a successful IT project.

In order to apply a successful risk management strategy, a project manager must consider the three factors of the "effective risk management": (1) the efficiency and the effectiveness of the processes within the project, (2) the influence of risks on IT projects, and (3) the human factor involved in the IT project.

(1) The "efficiency and the effectiveness of the processes within an IT project" dimension means that adopting a risk management strategy in an IT project helps to:

- increase the efficiency and the effectiveness of processes within the project; 
- clarify the processes within the project;

- obtain deliverables;

- positively influence the system quality;

- achieve overall project success.

(2) The "influence of risks on IT projects" dimension means that the risk management applied in an IT project has the following characteristics:

- it is conducted systematically, structured and on time (proactive and continuously);

- positively influences managers' decisions;

- helps identify risks continuously;

- helps classify and assess the risks correctly;

- reduces the probability of risks;

- reduces the possible negative impact of risks;

- reduces the overall exposure to risks (probability $\mathrm{x}$ impact).

(3) The "human factor involved in the IT project" dimension means that risk management in an IT project has the following properties:

- it is based on initial planning;

- it is taken into consideration in making decisions;

- it is transparent and dynamic;

- it takes into account the human factor (stakeholders);

- positively influences client satisfaction.

The main limits of this research are the sample size, the sampling technique, the unilateral perception of the project manager on the success/performance of the IT project, the choice of the transversal study (questionnaire) and the reluctance of the target population to fill out the questionnaire.

Future research directions can include subsample analysis, comparative study of the managers' perception and client perception over the IT projects results, and longitudinal studies for identifying the possible causes of specific relations between variables. We also suggest the analysis of correlations between the age of the respondent and different variables in the model, the study on objective performance indicators, not only subjective, the detailed study on different types of IT projects (software development, ERP implementationor outsourcing), the cluster analysis of different concepts and the variable analysis from a cultural perspective.

\section{REFERENCES}

[1] Agarwal, N., Rathod, U. (2006), Defining 'Success' for Software Projects: An Exploratory Revelation; International Journal of Project Management, no. 24, p. 358-370, Elsevier Sci Ltd;

[2] De Bakker, K.D. (2011), Dialogue on Risk. Effects of Project Risk

Management on Project Success, University of Groningen, Netherlands; 
Otniel Didraga, Claudiu Brandas, Lorena Batagan, Felician Alecu

[3] De Bakker, K.D., Boonstra, A., Wortmann, H. (2010), Does Risk Management Contribute to IT Project Success? A Meta-Analysis of Empirical

Evidence; International Journal of Project Management, 28 (5), 493-503;

[4] Chapman, R.J. (2017), The Rules of Project Risk Management; Routledge, ISBN-13: 978-1138247987;

[5] Didraga, O. (2013), The Role and the Effects of Risk Management in IT Projects Success. Informatica Economică 17 (1), 86-98;

[6] Fairley, R. (1994), Risk Management for Software Projects; IEEE Software, 11 (3), 57-67;

[7] Galorath, D. D., Evans, M. W. (2006), Software Sizing - Estimation and

Risk Management - When Performance is Measured Performance Improves;

Auerbach Publications, Boca Raton, FL;

[8] Górecki, J. (2018), Big Data as a Project Risk Management Tool, In book:

Risk Management Treatise for Engineering Practitioners, November 2018, DOI:

10.5772/intechopen.79182;

[9] Gray, A.R., MacDonell, S.G., Shepperd, M.J. (1999), Factors

Systematically Associated with Errors in Subjective Estimates of Software

Development Effort: The Stability of Expert Judgment. In: Sixth IEEE

International Symposium on Software Metrics, pp. 216-227;

[10] International Organization of Standardization (2018), ISO 31000: 2018.

Risk management - Guidelines, Geneva, Switzerland;

[11] Javani, B; Rwelamila, P.M.D., (2016).Risk management in IT projects - a case of the South African public sector; International Journal of Managing Projects in Business, Vol. 9 Issue: 2, pp.389-413.

[12] Jun, L., Qiuzhen, W., Qingguo, M. (2011), The Effects of Project

Uncertainty and Risk Management on IS Development Project Performance: A

Vendor Perspective; International Journal of Project Management, 29, 923-933;

[13] Na, K.-S, Simpson, J. T., Li, X., Singh, T., Kim, K.-Y. (2007), Software

Development Risk and Project Performance Measurement: Evidence in Korea;

The Journal of Systems and Software, no. 80, p. 596-605, Elsevier Science Inc.;

[14] Nidumolu, S. (1996b), Standardization, Requirements Uncertainty and

Software Project Performance; Information and Management, 31 (3), 135-150;

[15] Pimchangthong, D., Boonjing, V. (2017), Effects of Risk Management

Practices on IT Project Success. Management and Production Engineering

Review 8 (1), 30-37;

[16] Project Management Institute (PMI) (2017), A Guide to the Project Management Body of Knowledge (PMBOK ${ }^{\circledR}$ Guide) - Sixth Edition, PMI Inc.;

[17] Rabechini Junior, R., de Carvalho, M.M.(2013), Understanding the Impact of Project Risk Management on Project Performance: An Empirical Study; Journal Technol. Manag. Innov. 2013, Volume 8, Special Issue ALTEC, ISSN: 0718-2724, https://scielo.conicyt.cl/pdf/jotmi/v8s1/art06.pdf; 
[18] Rekha J.H, Parvathi R. (2015), Survey on Software Project Risks and Big Data Analytics, 2nd International Symposium on Big Data and Cloud Computing (ISBCC'15), DOI: 10.1016/j.procs.2015.04.045;

[19] Scheepers, C.B., Whelpton, P. (2018), 'Stakeholders' Different Perspectives of Critical Success and Risk Factors in a Case of Large-Scale System Implementation Across Africa'; South African Journal of Business Management, 49(1), a195;

[20] Shi, P. (2018), Disaster Risk Science; Springer, ISBN-13: 978-9811318511;

[21] Spacey, J. (2016),What is Risk Management Effectiveness?; March 09, 2016, https://simplicable.com/new/risk-management-effectiveness;

[22] Teymouri, M., Ashoori, M. (2011), The Impact of Information Technology on Risk Management; Procedia Computer Science 3, p.1602-1608;

[23] Wallace, L., Keil, M., Arun, R. (2004), How Software Project Risk Affects Project Performance: An Investigation of the Dimensions of Risk and an Exploratory Model. Decision Sciences 35 (2), 289-321;

[24] Wohlin, C., Mayrhauser, A.V., Host, M., Regnell, B. (2000), Subjective Evaluation as a Tool for Learning from Software Project Success. Information and Software Technology 42, 983-992;

[25] Zwikael, O.,Ahn, M. (2011),The Effectiveness of Risk Management: An Analysis of Project Risk Planning Across Industries and Countries; Risk Analysis, Vol. 31, No. 1, 2011, DOI: 10.1111/j.1539-6924.2010.01470.x. 